or peculiar thickened bast-fibre-like cells from underneath. The stem thus consists of three sets of tissues: (I) the limitary tissues, including epidermis, periderm, \&c. ; (2) the fibro-vascular bundles; and (3) the primitive tissue or Grundgezuebe of Sachs (see "Mo. Mic. Journal," vol, iii. p. I60). In an older dicotyledonous stem we find the limitary tissues becoming largely developed, cork-cambium and layers of cork being formed. The fibro-vascular bundles have also largely developed, the cambium cells by division, and the conversion of these new cells into permanent tissue has formed a number of annual rings of wood-cells and vessels as well as layers of bast, while the primitive tissue only increases very slowly in the medullary rays, the pith not increasing, and the primitive tissue under the epidermis becoming lost in the rapidly-developing bark. Such is the structure of a dicotyledonous stem.

In a monocotyledon we have the same tissues, limitary, fibro-vascular, and primitive. The primitive tissue is largely developed, forming the cellular tissue by which the fibro-vascular bundles are surrounded (Oliver, "Lessons," p. II3, fig. 68). These fibro-vascular bundles differ quite as much in the nature of their cells and vessels as those of the dicotyledon, often one form being developed in excess of the other. The limitary tissues also develop cork and other cells. There is thus very little difficulty in comparing a very young dicotyledonous stem with that of a monocotyledon. In the monocotyledons the fibrovascular bundles are closed, and therefore no annual layers are found; but in such stems as Dracæna, Aloe, Yucca, \&c., we have the stem increasing in diameter. The outer cells of the primitive tissue divide and form not only new primitive tissue but new fibro-vascular bundles (Sachs, "Lehrbuch der Botanik," ed. 2, p. I03, fig. 90). Prof. Williamson would probably call these Exogenous Endogens.

When we come to the Lycopod and Fern stem, we find the same parts-limitary tissues, fibro-vascular bundles, and primitive tissue. In ferns the bundles are more or less scattered, like those of the monocotyledon, while in the Lycopods we either have them separate or else all joined together to form a central axis (see Sachs, op. cit., figs. 66 and 89). Round this central axis in Lycopods we have the primitive tissue, while outside we have the epidermis often with peculiar thickened cells underneath, forming part of the limitary tissues. In Mosses, Charas, and Thallophytes we have only the primitive and limitary" tissues, the fibro-vascular bundles being entirely absent. In some of the Thallophytes, however, as in Lessonia, we may have the primitive tissue increasing just as in Dracæna.

In Lepidodendron, as in some of our modern Lycopods, we have a central axis of combined fibro-vascular bundles, and a large quantity of primitive tissue, no longer all parenchymatous, as in many of our recent Lycopods, but mostly prosenchymatous, as in L. chamcecyparissus. This primitive tissue went on increasing year after year, new cells forming by division, these being soon changed into hard prosenchymatous cells. Outside we have the limitary tissue strengthened, as in some of our recent species, by remarkable prosenchymatous cells. In Lepidodendron the primitive tissue was capable of dividing in the same way as that of Dracæna. The stem increased year after year, not by growth of the wood-cells, \&c., of the fibro-vascular bundles, as in a dicotyledonous stem, but by additions to the primitive tissue. I never denied that the Lepidodendron stem increased in diameter, but pointed out that the increase takes place by multiplication of the cells near the periphery of the primitive tissue, the portion not likely to be often preserved in Lepidodrendon stems. This mode of growth is quite compatible with the statement that the fibro-vascular bundles are closed as they are both in Ferns and Lycopods. As Prof. Williamson admits that "the large vascular cylinder of the fossil forms is a development of what is seen not only in Lyco- podium chamacyparissus, but in every one of the numerous Lycopods of which I have examined sections," there is no difficulty in settling the matter. The cylinder in L. chamacyparissus is part of the primitive tissue, not of the fibro-vascular bundles. Such being the case, the central axis of Lepidodendron is not a "vascular medulla," but a series of closed fibro-vascular bundles. In Lepidodendron we have merely a pseudo-exogenous growth taking place in the primitive tissue, while in Gymnosperms and Dicotyledons we have true exogenous growth in the fibro-vascular bundles. In Ferns this pseudo-exogenous growth is not likely to take place, as a fern produces only a few large leaves, while in a Lycopod or Lepidodrendron, which produces numerous small leaves, water for purposes of transpiration would have to be rapidly supplied in yearly increasing quantities. This is provided for by the increase which takes place in the wood-cells of the primitive tissue, not as in Dicotyledons, by additions to the wood-cells of the fibro-vascular bundles. Prof. Williamson has been led away by the mere superficial resemblance of the parts, and has never tried to understand the homologies of these stems. He has mistaken the united closed fibro-vascular bundles in the centre of the stem for a vascular medulla, i.e., for a portion of the primitive tissue ; and he has mistaken the woody cylinder surrounding this - which is a modified portion of the primitive tissue-for the united fibro-vascular bundles of a dicotyledon. After making two such fatal errors, can his proposed new classification be considered of any value?

W. R. M'NAE

\section{A NEW DYNAMETER}

T $T$ need not be said that in astronomical observation it is always desirable, to say the least of it, to have a tolerably correct estimate of the magnifying power actually in use. This has hitherto been only attainable either by means of the maker's valuation, or through the employment of the apparatus unfortunately termed a "dynameter," a word which every classical scholar would wish to see as soon as possible dismissed from circulation. The former alternative is, I am sorry to say, often far from reliable; the latter involves an outlay not within the reach of every astronomical student. The Rev. E. L. Berthon, Vicar of Romsey, Hants, well known already for many ingenious and valuable inventions, has recently devised a little apparatus for attaining the same object, which deserves high commendation. Its very moderate price places it within the reach of all; and its accuracy appears equal to that of instruments of more complicated construction and higher pretension. I have heard on excellent authority that very little dependence can be placed on the estimates of magnifying powers too frequently furnished to purchasers. Eyepieces are both constructed and rated too frequently by "rule of thumb," and their real, if measured, will be found widely different from their nominal power. Some opticians, as, for instance, the celebrated reflectormaker Short, have had an unfortunate reputation for exaggerating the power of their instruments, and without any suspicion of misrepresentation: such has been the case even at the celebrated Optical Institute of Munich, as appears by the corrections made by W. Struve in the numerical values of the Dorpat oculars, 94, I40, 2 I 4 , $320,480,600,800,1,000,1,500,2,000$, being respectively lowered by him on trial to 86, 133, I98, 254, $420,532,682,848,1,150,1,500$. In this instance, it is possible that some different mode of measurement may have led to the discrepancy. Uncertainty, it may be suspected, occasionally arises from this cause. I once undertook, at the special request of a friend, to verify with a doubleimage dynameter the power of some oculars constructed by a very eminent optician, whose name was an abundant guarantee for his good faith; but the results, on which I 
bestowed a great deal of care and trouble, trusting only to averages of many repeated measures, did not agree satisfactorily with the maker's statement. I do not know whether it may have been generally noticed, but the remark is a very obvious one, that the limit of numerical error increases with the power, so that in the case at any rate of ordinary dynameters, minute accuracy in the estimates of very deep oculars bears evidence of its own futility. If it represents anything of value, it can only be the care and attention with which a mean was deduced from repeated trials; but even this would be better expressed in round numbers, as less likely to convey an erroneous impression to the uninitiated.

Probably some form of apparatus may yet be devised which may secure greater minuteness in the measurement of very high powers, without entailing a disproportionate outlay. In the mean time Mr. Berthon's invention may be safely recommended as likely to prove of especial advantage to observers in general.

\section{T. W. WERB}

\section{THE NEW GANOID FISH (CERATODUS) RECENTLY DISCOVERED IN QUEENSLAND} II.

$\mathrm{T}^{\mathrm{T}} \mathrm{T}$ appears to me that there is not the least justification for 1 separating the living fish generically from that extinct form, the teeth of which are known by the name of Ceratodus. Immediately after its discovery became known, and before we knew more than the outlines of its external characters, views to the contrary were expressed, evidently based on the assumption that a genus was not likely to have survived from the Triassic epoch. This is certainly a remarkable fact, but it is not more surprising than the other, viz., that fishes from one of the oldest epochs from which fish remains are known, are most closely allied to Ceratodus. We know that the same specios occur on both sides of the Central-American isthmus-that is, that they. have existed at, and remained unchanged from, the time when the Pacific and Atlantic Oceans were connected by one or several channels. Therefore, it would appear that there is a greater persistence in the ichthyic type than we have hitherto been willing to admit.

Whoever has compared the teeth of Ceratodus runcinatus from the German Muschel-Kalk, and those of the Indian species described by Prof. Oldham, with the teeth of the living species, must admit their generic identity ; and if the Australian form really grows to the enormous size stated by some colonists, 1 have no doubt that the teeth of such large examples cannot be distinguished from the fossils mentioned. So close a resemblance in highly specialised teeth like those of Cerat:dus is generally admitted to be of generic significance. Unfortunately no other part of Ceratodus is known to have been preserved in the fossil state to serve as a further guide in answering this question. The strata in which the teeth are found must have been much disturbed, as no two teeth have ever been met with in situ together; but I cannot help thinking that sooner or later the vomerine teeth will be recognised. From their smaller size they would easily have escaped observation; and their shape (which differs so much from that of the molars) would scarcely have allowed an observer to connect them with the genus to which they in reality belong.

The next most nearly allied forms are the American and African Lepidosirens, a genus at present unknown in a fossil state. 'The skeleton (in some respects even to its minute details), structure of the fins, dentition, internal nostrils, three-chambered heart, co-existence of a lung with gills, intestinal tract, small size of ova : all present the strongest possible evidence of the close relationship between these fishes. The points in which they differ are of such a nature that characters indicative of an amphibian affinity in Lepidosiren are modified in Ceratodus according to a distinctly ichthyic type, thus tying, as it were, Lepidosiren firmly to the class of fishes. The longitudinal valves in the bulbus arteriosus of Lepidosiren, reminding us of a similar structure in the heart of Batrachians, are replaced by truly Ganoid valves in Ceratoans; the imperfect gills of the former genus are as perfect in the latter as in any other fish; the lungs of Lepidosiren, paired as in a frog, are confluent into a single air-bladderlike sac in the Australian form; instead of the closed ovaries with a developed oviduct and fallopian tubes of Lepidosiren, we find the ovaries of the Barramunda open, discharging the ova into the abdominal cavity, as in the Salmon family and other fishes. These differential characters may be considered by some of sufficient importance to refer the Lepidosirens and the Barramunda to two distinct groups.

Some of the oldest fishes, known from the Devonian epoch, are designated by the names Ctenodus and Dipterus. Whether they should be referred to one genus or two is a question about which opinions are divided, and into which I need not enter here. They are evidently representatives of the same ichthyic type as the Dipnoi of the present epoch. The similarity of the large molars to those of Ceratodus has been recognised for a long time; but it is only recently that $\mathrm{I}$ have been able to ascertain, in an example in the Jermyn Street Museum, the presence of a pair of small vomerine teeth. Moreover, the same example presents as good evidence as we can expect in a fossil, that the nostrils areplaced within the mouth. These characters are combined with the presence of acutely lobed paddles, and of a notochordal skeleton ; but there is the great difference that the end of the vertebral column is heterocercal, instead of being diphyocercal, as in Lepidosiren and Ceratodus. Therefore Ctenodus will form the type of a distinct dipnöous family.

Thus, then, we arrive at the conclusion that Lepidosiren, far from being an isolated representative of a distinct subclass of fishes, is only one of the representatives of a suborder of Ganoid fishes, characterised by the position of the nostrils within the mouth, by paddles supported by a jointed axis, by lungs co-existent with gills, by a notochordal skeleton, and by the absence of branchiostegals. The term "Dipnoi" may be retained for this sub-order, which was developed in the earliest epochs from which fish-remains are known, while we have scanty evidence of its presence in Liassic and Triassic strata, and, in the present state of our knowledge, it appears to be lost; until we find it again represented by three living forms in the present period. Probably some other extinct genera belonged also to this sub-order, but their remains are in too fragmentary a condition to admit of an exact definition of their affinities.

During the examination of Ceratodus; I had so frequently occasion to refer to structural peculiarities of the Plagiostomata (Sharks and Rays), that I was induced to reconsider the relations existing between this sub-class and the Ganoid and Teleosteous fishes; and I came to the conclusion that the two former are much more nearly allied to each other than the Ganoids are to the Teleostei. The Plagiostomes were considered to be a distinct sub-class of fishes on account of the highly-developed state of the organs of reproduction in the female, besides the presence of copulatory organs in the male. Their ova are different from those of other fishes, having a very peculiar sliape, and shell with adhesive appendages, and being of an unusually large size, and few in number. They are impregnated internally; some of the species are viviparous. They have from five to seven external gill-openings. Although in external appearance a Ray and a Shark are apparently very different, yet these extremes are connected by a number of intermediate forms, and they form altogether one of the most homogeneous groups in the zoological system. 